Komporaly, Jozefina. "Translating Hungarian Drama for the British and the American Stage.” Hungarian Cultural Studies. e-Journal of the American Hungarian Educators Association, Volume 14 (2021): http://ahea.pitt.edu DOI: 10.5195/ahea.2021.434

\title{
Translating Hungarian Drama for the British and the American Stage
}

\section{Jozefina Komporaly}

\begin{abstract}
Reflecting on my experience of translating contemporary Hungarian theater into English, this paper examines the fluidity of dramatic texts in their original and in translation, and charts collaborations between playwrights, translators and theater-makers. Mindful of the responsibility when working from a "minor" to a "major" language, the paper signals the discrepancy between the indigenous and foreign 'recognition circuit' and observes that translations from lesser-known languages are predominantly marked by a supply-driven agenda. Through case studies from the work of Transylvanian-Hungarian playwright András Visky, the paper argues that considerations regarding such key tenets of live theater as "speakability" and "performability" have to be addressed in parallel with correspondences in meaning, rhythm and spirit. The paper also points out that register and the status of certain lexical choices differ in various languages. Nuancing the trajectory of Visky's plays in English translation, this paper makes a case for translations created with and for their originals, in full knowledge of the source and receiving cultures, and with a view to their potential in performance. The paper posits the need for multiple options encoded in the translation journey, including hypothetical concepts for future mise-enscène, and situates the translator as a key participant in the performance making process.
\end{abstract}

Keywords: András Visky, stage translation, dramaturgy, collaborative creation, mise-en-scène, Foreign Affairs, Theatre $Y$

Biography: Jozefina Komporaly lectures at the University of the Arts London and translates from Hungarian and Romanian into English. She is editor and co-translator of the drama collections How to Explain the History of Communism to Mental Patients and Other Plays (Seagull Books, 2015) and András Visky's Barrack Dramaturgy: Memories of the Body (Intellect, 2017), and author of numerous publications on theater, translation and adaptation, including the monograph Radical Revival as Adaptation: Theatre, Politics, Society (Palgrave, 2017).

Her translations have appeared in Asymptote, Hungarian Literature Online, Index on Censorship, Modern Poetry in Translation, Poet Lore, Words without Borders, and World Literature Today, and have been staged by Foreign Affairs in London and Theatre Y and Trap Door in Chicago. Recent translations include Mr K Released by Matéi Visniec (Seagull Books, 2020 - shortlisted for the 2021 EBRD Literature Prize) and The Glance of the Medusa by László F. Földényi (Seagull Books, 2020). Current projects include the anthology Plays from Romania:

Dramaturgies of Subversion (Bloomsbury, 2021), and an audio adaptation of Matéi Visniec's Decomposed Theatre for Trafika Europe Radio. She is a member of the UK Translators' Association and the Translation, Adaptation and Dramaturgy working group of the International Federation of Theatre Research. j.komporaly@wimbledon.arts.ac.uk 
Komporaly, Jozefina. "Translating Hungarian Drama for the British and the American Stage." Hungarian Cultural Studies. e-Journal of the American Hungarian Educators Association, Volume 14 (2021): http://ahea.pitt.edu DOI: 10.5195/ahea.2021.434

Reflecting on my experience of translating contemporary Hungarian drama into English, this paper aims to examine the fluidity of the dramatic text, both in the original and in translation, and to chart long-term collaborations between playwrights, translators and theatermakers. I aspire to contribute to translation flows between relatively small literatures on the semi-periphery and the hyper-center that is English, and with reference to Lawrence Venuti's views in The Scandals of Translation (1998), I ponder on the fault lines between translations assimilating a foreign text to the translating culture and, conversely, aiming to signal uniqueness and difference. I acknowledge the necessity of embedding both source (i.e., foreign) and target (i.e., translated) texts into their respective cultural norms, and wish to emphasize the paramount importance of negotiation between the two, rather than privileging one to the detriment of the other. With the dual affiliation of drama - as a literary genre and above all a blueprint for performance - we are dealing with the additional need to consider carefully the exact destination of the translated work, and ideally create versions in foreign languages that respond to the conditions of their reception in the here and now. I am thinking about these issues in the parallel capacites of academic and translator, having taught drama and theater studies in various UK universities alongside working as a freelance literary translator from languages I acquired from birth (Hungarian and Romanian) into English, which is the language of my habitual use. I feel privileged to belong to more than one cultural and linguistic context, being a migrant in another language as well as place, as I believe that this experience offers a fertile terrain for transnational exploration and for building genuine cultural associations.

In my view, translations shed light on the interplay between the familiar and the unknown, and in this respect are part of a continuum of texts where the question of native versus foreign is not necessarily the main concern. I wish to interrogate the issue of ownership over language, proposing instead a model whereby languages are available for cultural reclamation by anyone who has the interest and ambition to extend, in Wittgenstein's famous words, the limits of their world. As Xiaolu Guo has pointed out, writing in another language can help convey ideas that it may not be possible to communicate in one's first language (in her case writing in English is a political act that opens up a pathway for bypassing censorship), and she also notes that one language is insufficient to express her thoughts. For this reason, she translates, and uses one word to find another: trying to write "a text that is alive and true for both cultures" (Guo 2016). For me, translation is a form of creative practice, and I can relate to the reluctance of limiting oneself to one language. I suggest that translation is above all a dialogic phenomenon that braids together rather than separates, and should also be rooted in the translator's parallel expertise in both the target and source cultures. In this way, my concern is neither with achieving an entirely independent cultural product, nor with the overlap between translation and imitation in a zealous plea for over-faithfulness, but with instituting a practice whereby translations are written with and for their originals, and are inscribed into a continuum of works informing and commenting on one another.

Historically, the dominant pattern in the Anglo-American theater tradition has privileged the familiar over the unknown, and offered exposure to works that fit most neatly with current trends in indigenous playwriting. The latter has been further fueled by the largely unchallenged practice of commissioning native playwrights to create English- language versions of foreign plays, generally based on literal translations, and in this process edit out the direct lineage to another, culturally and linguistically distant, precursor text. This practice by definition hinders the celebration of difference, and severely limits the palette of dramaturgical trajectories in the English-speaking world. In the terminology of Lawrence Venuti (articulated in Venuti 1998) 
Komporaly, Jozefina. "Translating Hungarian Drama for the British and the American Stage." Hungarian Cultural Studies. e-Journal of the American Hungarian Educators Association, Volume 14 (2021): http://ahea.pitt.edu DOI: 10.5195/ahea.2021.434

such "domestication" reduces the foreign cultural norms to target-language cultural values and "violently" erases cultural values, creating a text which appears to have been written in the target language and follows the cultural norms of the target reader or audience. To counter this bias, theater translation has a political as well as an aesthetic mission. Navigating the spectrum between domestication and its polar opposite, Venuti's "foreignization" - the strategy of retaining information from the source text - I believe it is the translator's responsibility to deal with the slippery interface between making a translated work accessible and relatable in the target culture, while maintaining its distinctive cultural specificity. Encouraging excessive fluency and naturalness in English, for instance, may appear as the best way of acculturating a given cultural artefact into the indigenous canon, or at least making it appeal to a local audience, but this often comes at the risk of depleting the translated work of its inherent stylistic individuality. In my practice, I resist wherever possible the tendencies of the dominant target culture to assimilate the differences of the source. In trying to signal these, however, I have found that actors have to be able to actually deliver their lines as effortlessly as possible, therefore a text's potential for being uttered and performed on stage, known as "speakability" and "performability," must be addressed in parallel with correspondences in meaning, rhythm and spirit. These are two notions, often regarded as fundamental to live theater, which represent the oral/acoustic and the gestic/action dimensions of the dramatic text. It is also essential to acknowledge that different linguistic registers operate in different ways in various languages, and we need to take on board the variation in status of certain terms and lexical choices. They can open up connotations that may not exist in the other culture, and conversely, substituting terms with target-language equivalents without considering the full spectrum of potential associations, can lead to a form of domestication that simply obliterates the foreign, or brings the new version into the realm of adaptation. In the following, I offer examples from my translation process via case studies taken from András Visky's dramatic work. Transylvanian-Hungarian playwright, poet and dramaturg András Visky (born 1957) is an increasingly prominent literary figure in Hungary, too, whose plays have been widely translated and staged internationally. I edited the first English-language critical anthology of Visky's work (Komporaly, ed., 2017) and have written about his playwriting in several publications, including Komporaly 2020. This latter essay is additionally significant because it acknowledges the role of Eastern European authors within the Continental playwriting canon and opens up much-needed transnational comparative perspectives.

Prompted by major events in the second half of the twentieth century, by what we might call history on a macro level, Visky writes intimate plays centred on a handful of characters and examines events from the perspective of history on a micro scale. Visky's plays invite a critical re-examination of history and offer a framework for repositioning personal experience and memory in theatrical performance. Visky's work stems from the author's experience of communism in Romania, which was arguably the most oppressive totalitarian regime in the Eastern bloc. Equipped with personal memories and found stories, Visky is in a perfect position to reflect on history, "connecting the past with the present through the creativity of the theater, constantly 'quoting' from the past" (Rokem 2000: xiii). To this end, he deploys a style that does not shy away from ironic scrutiny. Moments of heroism that verge on the tragic also acquire a comic edge, and as a result, Visky's work deliberately blurs the boundaries between artistic genres. 
Komporaly, Jozefina. "Translating Hungarian Drama for the British and the American Stage." Hungarian Cultural Studies. e-Journal of the American Hungarian Educators Association, Volume 14 (2021): http://ahea.pitt.edu DOI: 10.5195/ahea.2021.434

In addition to this awareness of the playwright's political and aesthetic concerns, when translating I am also mindful of the political responsibility when working from a "minor" to a "major" language. I am motivated by my insider knowledge of the source-culture and a frustration with the limited representation of contemporary Hungarian drama in English translation, the latter also coupled with my dissatisfaction with the discrepancy between the indigenous and foreign "recognition circuit." Translations from lesser-known languages such as Hungarian are predominantly marked by a supply-driven agenda, rooted in the commitment of translators and the relative unfamiliarity of readers and publishers in the English-speaking world with these, hence much work is translated on spec and translators actively cold-pitch projects effectively doing the work of literary agents. Acting as a translator, critic and agent all at once, I often embark on projects because I want to champion innovative authors: in the case of Visky, proposing his play Temetetlenek. A sötétség szentje ['The Unburied: The Saint of Darkness'] for London-based theater company Foreign Affairs' theater translations program as part of an open call for submissions. Needless to say, I wanted this work to reach an audience in English yet was reluctant to achieve that at the cost of blurring the boundaries between the different contexts of contemporary theater cultures in the UK and continental Europe. For this reason, I was particularly careful to steer clear of interventions that might transform the translation into a version that only loosely evokes the initial text. Fortunately, theater translation is seen by Foreign Affairs as a respectful and mutually negotiated pathway for accessing culturally distant or different works, so we were able to reach agreement on finding the benchmark where the source text was still identifiably foreign, yet intelligible and relatable in the target culture. To a degree, any work by Visky charts this territory, as they are almost simultaneously received in their original and in another culture that accesses it through the medium of translation. Visky's theater stems from the Transylvanian province of Romania and, whilst it is written and performed in Hungarian, it is intended for an audience that, by default, also includes native speakers of Romanian. The Hungarian Theater of Cluj, for instance, where Visky's stage plays have premiered, routinely subtitle their productions in Romanian, and increasingly in English too, thus aiming to be an inclusive platform for theater spectatorship rather than merely serving a local, linguistically homogenous community, and in this sense being 'only' a minority theater.

Visky has come to playwriting after a decade of working as a dramaturg and collaborating with some of the most established names in Hungarian and Romanian theater. He claims that 'the prospective performance knows immeasurably more about the text than the author' (compare Visky's introductory notes to his play Pornó ['Porn'], in Komporaly, ed., 2017: 214) and has repeatedly declared that a play is not fully finalized until it is performed. Visky's writing demonstrates an understanding of the processes of theater practice that is relatively rare in the Hungarian theater landscape, as his playtexts are open to multiple interpretations: since these are performed, they are unconstrained by the pressure of being canonized in the way that works of Hungarian literature often are. It is for this reason that his plays offer a genuine opportunity for the renewal of Hungarian theater language, and since they are originally intended for the stage and not the page, Visky's plays "only start their quest towards literary canonization after having gone through the 'purgatory' of theatrical performance" (György 2007). For Visky, playtexts offer an opportunity for further exploration by other parties, and he gives the latter total creative freedom. A Romanian production of Júlia ['Juliet'] (at the National Theater of Cluj), for instance, used only a relatively small section of Visky's script and included elements of improvisation and group collaboration in response to a stimulus, while English-language productions favoured textual variants staged in different 
Komporaly, Jozefina. "Translating Hungarian Drama for the British and the American Stage.” Hungarian Cultural Studies. e-Journal of the American Hungarian Educators Association, Volume 14 (2021): http://ahea.pitt.edu DOI: 10.5195/ahea.2021.434

translations for US and UK productions. When translating Visky's plays it is important to be maximally sensitive to his open dramaturgy and original dramaturgical concept barakk dramaturgia ['Barrack Dramaturgy'], first published in English in The Routledge Companion to Dramaturgy (2014). Barrack Dramaturgy allows participants, both performers and audience members, to access the repressed body memories of historical traumas, which they can then verbalize and narrate. According to Visky, performers and audience simultaneously relinquish their freedom for the duration of the performance, and are bound by a contract of sorts towards a shared experience: an enclosure into a claustrophobic space in which the performance and spectating areas are not separated. The performance begins with this joint act of huis clos and finishes with an equally shared exit or liberation through which we are invited to explore our potential for participatory understanding (Visky 2014: 468). For Visky, the fact that both performers and audience are shut in together with the aim of remembering heightens the perception of the performance as an event in the present, and is predicated on total audience involvement, because its aim is to lead to a shared embodied experience. Actress and Theatre Y artistic director Melissa Lorraine connects this shared experience with a celebration of the very essence of theater, pinpointing the miraculous solidarity of strangers sharing a moment (Lorraine 2015).

There are barely any stage directions and very limited indications regarding setting and exact timeframes, therefore the play can take place potentially anywhere at any point in time. Being an author who considers the playtext as a mere blueprint towards subsequent stage productions, Visky is known for his generosity in terms of co-operating on the mise-en-scène and allowing edits. Embracing a post-dramatic approach to theater making, Visky acknowledges that the textual is only one dimension of a performance, so his scripts are relatively concise, allowing the subsequent development of theatrical images. Visky states that engagement with a dramatic text

takes place by way of the text in action, i.e. through the placing of a written text into a nonverbal 'formation,' which is nothing other than the performance, born in front of the audience, only to vanish later. The written text is in fact a document of a multimedia event that took place in the past: hence the play is always open and, indeed, unfinished. The text of a play is an invitation not only to enter the space of linguistic expression, which provides us with endless possibilities, but also to sense and interpret this space (Visky in Komporaly, ed., 2017: viii).

Recurrent themes addressed by Visky include the body, trauma, coming to terms with the past, mother-daughter relationships and generational lineage, our duty as humans in the face of political atrocities/crises, the pressure of conventions/expectations and rebellion against them. The first Visky play I translated, The Unburied: The Saint of Darkness reunites many of the above themes, and it is written for ten voices: Teresa, young Teresa, Father, a Priest, Soldier, Sister Beata, The Voice, St. Peter, Man, Tempter. At first sight, the play is an allegory of Mother Teresa's life, establishing a parallel between her sense of vocation and Antigone's sense of duty to bury her brother. They both defy the values of the respective systems in which they live, Teresa first leaving her homeland for India, and then the order of the Sisters of Loreto, to fulfil her true calling: to care for the genuinely needy, "the unburied." "The sea of unburied bodies" is a recurring metaphor in the play, which not only links Teresa's life to that of Antigone, but also foregrounds the current migration crisis. The need to bury the dead, be it Teresa's own mother, or nameless characters, is an act of justice, a way of coming to terms with the facts of life, and an 
Komporaly, Jozefina. "Translating Hungarian Drama for the British and the American Stage." Hungarian Cultural Studies. e-Journal of the American Hungarian Educators Association, Volume 14 (2021): http://ahea.pitt.edu DOI: 10.5195/ahea.2021.434

acceptance of responsibility for our acts as human beings in a globalized world. While the play is embedded in Christian iconography, it is never dogmatic, and it is particularly lighthearted when Teresa encounters St Peter. As a cultural commentator, Visky argues for the need to reinterpret religion to fit our contemporary circumstances, and to allow it to be impacted by the world that surrounds us. He likens the religious and theatrical experience to one another, both being existential and, channelling eminent theater scholar Peggy Phelan (Phelan 1993), ephemeral activities where only those physically participating in the moment can have importance.

Bearing these considerations in mind, there are multiple approaches available to the translator and in the course of my process, developed with Foreign Affairs theater company with a view to a rehearsed reading in December 2016 and a full production in November 2017, I experimented with different levels of interpretation. Initially, I created a relatively open text, in fairly neutral language, that felt like a blank slate that could be explored in rehearsal. At this stage, I did not want to pin down who Teresa was, whether she was the real Mother Teresa or a vehicle for more contemporary responses. I wanted to examine whether it was possible to create a text in English (as it is in Hungarian) that allowed for multiple interpretations simultaneously. I know from personal conversations that the playwright wrote the play feeling powerless in the face of the current migration crisis and the stance of official Hungarian politics, yet there is not a single word in the text that makes this connection explicit. In the absence of Hungarian productions of the play, we could not rely on precedents, but felt that in our mise-en-scène connotations of contemporary situations should be explored. So, my dilemma as a translator was whether I should make connections to the political situation in Hungary - could Teresa be a Hungarian girl watching as her government clamps down on the country's borders? - or, rather, could I consider referencing a local context in the UK, such as a modern-day girl on a Hackney housing estate, seeing that Foreign Affairs work in this London borough? Also, would the exchanges between the young girl and the father be happening today or in the past: what does universality and timelessness really mean in terms of translation? The more I unpicked these possibilities, the more I realized how all this needs to influence the translation early on, and how this unavoidably impacts the voices of the protagonists, especially the older and the younger Teresa. In my first draft, I created what could be termed a literal version, trying to stay as close as possible to Visky's choices in terms of register. Visky tends to avoid dialect and sociolect in his plays, as his work is affiliated to the non-representational trend in theater that is structured by ritual, metaphor and poetic imagery. Viewed from an Anglo-American perspective, his register is relatively high; however, this is not intended as an obstacle to relatability, but a way to mark universality and inclusiveness: these plays could potentially be relevant to anyone, and the situations addressed in them are applicable in multiple circumstances. The play incorporates fragments from Mother Teresa's own diary, so I wanted to integrate extracts from the English edition of her Come Be My Light (2007). As I layered my translation with quotes from this source, I found that this automatically heightened the register even further and introduced a cluster of Latinate terms, such as moribund, divulge, emanate, depart, and some archaic/biblical ones, such as spouse, I thirst. Following the style of Mother Teresa's private writings, I refrained initially from spoken language structures, peppering my version with the likes of cannot, they are, I shall. In other words, my choices were intentionally loyal to the source text and not primarily concerned with the additional challenge for performers and indeed the expectations of theater audiences, used to hearing spoken language in such situations. 
Komporaly, Jozefina. "Translating Hungarian Drama for the British and the American Stage." Hungarian Cultural Studies. e-Journal of the American Hungarian Educators Association, Volume 14 (2021): http://ahea.pitt.edu DOI: 10.5195/ahea.2021.434

At this point, I tested out my translation with a group of actors as part of my collaboration with Foreign Affairs Translates, a team that responded very positively and with great professionalism to the challenge. I realized that skilled actors can convey any text and make it engaging; however, the connotations of the work in performance might be other than those initially intended or anticipated. Unlike the Hungarian version where, despite citations from Mother Teresa, the text can maintain is openness and universality, in English translation this was not necessarily the case, and by layering my version with another historically distant translation, I was actually situating the new English language text in a time and space that I did not intend. Also, by citing Mother Teresa verbatim, I was making a definite choice prior to the rehearsal stage and prior to discussions with the theater company regarding the precise identity of the protagonist. This realization made me choose to translate the verbatim extracts from Mother Teresa's diaries myself, rather than borrow from the existing "established" version and remove some of the Latinate and high-register words. My main motivation in this was not to domesticate the translation, but to highlight the idea that the Teresa figure is an ordinary woman, to whom extraordinary things have happened. She even comments that "Antigone would talk in beautiful verse, something I'm unable to do" (Scene 2, p. 2), thus allowing her to sound like an average person becomes a matter of utmost urgency, overriding concerns of linguistic equivalence or parallel registers between source and target languages. Thus, I swapped moribund for dying, vocation for calling; divulge for give away; opt for for settle on/go for; emanating for pouring out; attending to for minding; depart for go/be off and slip away'; repeat for say it again; disperse for scatter; spouse for beloved; I thirst for I'm thirsty; and introduced abbreviations to mark spoken language structures such as can't or they're, as I wanted to avoid Teresa sounding formal.

I believe that this level of intervention has allowed the translated text to approach the sense of universality inhering in the Hungarian original, despite deploying vocabulary of a different register. In other words, reverting to strategies from the arsenal of domestication has ended up playing a different role in this context, and in my view, contributed to situating the translated English text in a closer dialogue with its precursor than if I had slavishly implemented the closest correspondent for each and every word. Being prompted by a desire to create a translation with and for its original, I was able to achieve a continuum of works informing and commenting on one another. In this sense, I feel that I was closely attuned not only to the actual dramatic text in Hungarian but also its cultural significance in an indigenous context and its afterlife in performance. I am of course aware that in the event of further potential performances in English, novel decisions may need to be taken as to the identity of Teresa and the actual cultural context in which she operates.

Serving up such conundrums, Visky's play is painfully topical: written in 2016 and originally intended for the radio, its polyphonic qualities and visual richness instantly invite ideas of staging in live theater conditions. The Unburied: The Saint of Darkness is simultaneously a chamber piece, a family drama, and instance of post-dramatic theater and a strong political and philosophical play, as it reflects on the current international migration crisis through a strong central protagonist, the figure of Mother Teresa of Kolkata. It draws on aspects of Mother Teresa's biography and even integrates elements of her journals, yet it is not a play solely about a particular individual in particular situations but a metaphor for universally valid human concerns. Being "other" in a hostile environment is a recurrent trope in the play, as is the question of belief and doubt and the subtle negotiation between the two. Love and temptation in their manifold manifestations also underpin the play, therefore one of our concerns when workshopping the text 
Komporaly, Jozefina. "Translating Hungarian Drama for the British and the American Stage." Hungarian Cultural Studies. e-Journal of the American Hungarian Educators Association, Volume 14 (2021): http://ahea.pitt.edu DOI: 10.5195/ahea.2021.434

was to ponder on questions of identity and try to figure out who this Mother Teresa figure might be for us. Visky creates a fluid sense of temporality, juxtaposing images of Teresa at various ages and stages of her life, in this way overlapping past, present, and future, and arguing for a quasi-mythical and cyclical sense of time that cannot be taken too literally even if it also resonates with the here and now. Thus, for instance, for the initial production, where the play was situated alongside others in a theater translation showcase, more than one language was necessary. So after meticulously translating Visky's words into English, I "smuggled back" snippets of the original Hungarian to do justice to the character's nuanced polyphonic qualities and to suggest this sense of otherness and dislocation that underpins the play. For the full production by Foreign Affairs in 2017, however, the various selves of Teresa were embodied by four different performers, themselves coming from various cultural backgrounds. It was, therefore, superfluous to introduce a literal layer of "foreignness" as a multitude of accents were already present in the production.

This process of collective creation with the performers over an extended period of time enabled me to test my translation of Visky's play on an ongoing basis, having it read, discussed and then performed by the ensemble in an actual rehearsal environment rather than in the privacy of my office. Thus, the English-language version came about as a result of a stratified process that included interrogating embodied words and attending to the inherent physicality of the text. In this way, the process of translation went beyond being a merely intellectual exercise, and capitalized on the presence of mentors and fellow translators in addition to an ensemble of performers available to respond to the text. In sum, this was an example of an ideal case scenario, whereby theater-translation is a form of collaborative theater-making practice generously expanded in time, and in which the translator also acts a dramaturg and as part of the creative team.

Following on from this rewarding process of collective creation, my next collaboration with Visky was on a series of short plays entitled A test történetei ['Stories of the Body'] that went into production at Chicago's Theatre Y in May 2018 and ran in repertory to great critical acclaim. The plays in the series grew out of The Unburied - now revised and retitled Teréz ['Teresa'] - and this is particularly relevant because the English translation was staged prior to the Hungarian original, and prior to the publication of the entire cycle in either language. An initial incarnation of the first play appeared in Hungarian in the literary magazine Látó ['Seer'] in October 2017, just a month before the same text was staged in London. This is a relatively rare situation in both the theater and indeed the translation world, as English versions are usually commissioned in the wake of successful translations into other languages and plays in English translation tend to get produced only following extended runs in the source culture and/or other languages. The reason for this leap of faith was the ongoing collaborative relationship between Visky and Theatre Y, and the impact of the English-language drama anthology of Visky's work I have edited, András Visky's Barrack Dramaturgy: Memories of the Body, in which I strove to involve a multiplicity of voices, including performers and directors affiliated with the company. For the latter, the relevance of Visky's aesthetic to their own concerns was key. The plays comprising Stories of the Body are all based on real-life stories as experienced by remarkable women (including Mother Teresa and Italian Renaissance painter Artemisia Gentileschi), and connected to various cities including Budapest, Cluj/Kolozsvár, Kolkata and Rome, from the seventeenth- to the twenty-first century. The plays themselves are works of fiction, rooted in the technique of open dramaturgy. As Visky recommends, theaters might want to put on various combinations of the plays, and as a result, spectators could watch different productions each 
Komporaly, Jozefina. "Translating Hungarian Drama for the British and the American Stage." Hungarian Cultural Studies. e-Journal of the American Hungarian Educators Association, Volume 14 (2021): http://ahea.pitt.edu DOI: 10.5195/ahea.2021.434

time, perhaps in a different order. In this way, the plays (Teresa, Lina, Eva and Artemisia) - and their approximately fifty-minute-long stage versions - would gain new meanings in each other's light and context: illuminating the stories of the body in the most varied refractions, as a variation of a single theatrical space and set design. The plays also have the potential to be staged in their own right, of course, as full-length performances.

Strong female protagonists are a trademark of Visky's theater. The play that launched him as a dramatic author was prompted by the personal history of his mother (Juliet) and subsequently he dramatized a traumatic event experienced by his wife (Porn). Megöltem az anyámat ['I Killed My Mother'] pays homage to another personal history, of a close friend, yet none of these works are examples of documentary theater but deeply poetic responses to universal experiences such as love and loss or mother-daughter/child relationships, albeit embedded in hostile social and political conditions. Teresa focusses on scenes from the life of the young Mother Teresa, dramatizing her initial departure from home and highlighting her hesitation with regard to faith, while Artemisia draws on the life of the first professional female painter, and the court case that she wins against her rapist, an influential male public figure. Eve based on interviews with a Hungarian sex worker, a Roma, unwanted, abused, and trafficked, who struggles to claim a life of her own based on trust and dignity. The play explores the traumatized psyche of a truly innocent person who will struggle to redefine happiness as long as this world is set out to consume the weak. Lina dramatizes the trauma of a friend, in a whimsical exploration of the mutilated body, celebrating the capacity for re-learning movement through the still dance of the dragonfly, and through love and forgiveness.

As far as the translation process of Stories of the Body is concerned, the English versions were commissioned by Theatre $\mathrm{Y}$ in a manner replicating the relatively tight rehearsal and production timelines in contemporary Western theaters. Due to the limited time and geographical distance, we did not get to mull over details in the leisurely manner experienced with The Unburied; however, there were concerted efforts to conduct an ongoing negotiation between playwright, theater company and translator. Seeing that creating a definitive version is a contradiction in terms when it comes to stage translation, our strategy was to Americanize the translation (opting for US variants such as "mom" rather than "mum"), offering alternatives in a number of situations and, above all, encouraging actors to substitute terms as needed in the course of the rehearsal process. This helped actors with generating a sense of ownership over the material and with feeling more comfortable with the words and hence the identity of their characters. The distinctive features of the plays that needed most attention included repetitive and fragmented lines, overt intertextuality, monological structure and emphatic musicality, all recognizable attributes of postdramatic theater. ${ }^{1}$ Having said that, these four plays, like other Visky dramas such as Porn, I Killed My Mother, Visszaszületés ['Born for Never aka Backborn'], defy categorization insofar as each is a unique theatrical event that is simultaneously transnational and distinctively (Eastern) European, being based on clearly identifiable local

\footnotetext{
${ }^{1}$ The concept of postdramatic theater was first introduced by German theater scholar Hans-Thies Lehmann (in Lehmann 2006), summarizing a cluster of tendencies in avant-garde theater since the late 1960s. The theater that Lehmann calls postdramatic is not primarily focussed on drama, but evolves a performative aesthetic in which the textual dimension of the performance is put in correlation with the cultural and material conditions of the performance and the stage.
} 
Komporaly, Jozefina. "Translating Hungarian Drama for the British and the American Stage.” Hungarian Cultural Studies. e-Journal of the American Hungarian Educators Association, Volume 14 (2021): http://ahea.pitt.edu DOI: 10.5195/ahea.2021.434

realities. Among the many challenges we faced was solving the conundrum around csonk ['stump']/csonka ['maimed', 'mutilated', 'incomplete'], used by Visky in Lina to refer to a limbless person as well as the loss of territory by Hungary following the First World War. After extensive deliberation, we felt that using the same word across the board was less successful in English, even if this meant renouncing some of the repetitive rhythm and intertextual complexities inherent in the original. It was also important to acknowledge existing usage in terms of historical references to Hungary at the time, thus, csonkaság ended up translated as "incompleteness," while Csonka-Magyarország became "maimed Hungary" and csonk was generally translated as "stump." The latest incarnation of my work on Stories of the Body reconnects my preoccupations with translation and theater criticism, via the collection I edited and translated, Plays from Romania: Dramaturgies of Subversion. In this volume (forthcoming in October 2021), I have included Visky's drama cycle alongside other plays that deal with Romanian realities, with the aim of generating interest in the subject matter and these diverse dramatic modes of expression. Thus, the plays span the period from the 1980s to the present day and offer an insight into the variety and vitality of transnational dramatic practice in Romania. In this collection, I reverted to British usage and endeavoured to create versions that have a potential to be enjoyed as stand-alone readerly experiences, whilst also showing promise for subsequent stage productions. In order to contextualize this work for readers unfamiliar with Romanian conditions, I introduce the volume with an essay on the contemporary theater landscape - and in this sense it is a hybrid academic-translation project. However, I am hoping that the book will appeal to the theater profession and that some of the plays will be produced in the future. A few rehearsed readings have already taken place, but I am of course aware that subsequent revisions are more than likely to take place once there is an interest in staging the plays, and these negotiations will naturally be rooted in the specific conditions of the prospective project.

Looking back on my experience as a translator, I believe that it is essential to give more creative space to translators working as part of companies and ensembles, and whenever possible involve them throughout the staging process. In my view, so-called literal translations should be scrapped; translations need to be developed with the help and for the benefit of their originals, in full knowledge of the source and receiving cultures and the particular agendas of the creative teams. Being able to navigate between the two worlds is an essential requirement for any translator, but for theater translators it is additionally key that they at least consider the stage potential of the work they are dealing with. In an ideal situation, translations are commissioned for a given production, and hence the dialogue with the ensemble is at least available in theory, but even when translations are created in other circumstances, I am in favour of translations that incorporate hypothetical concepts for a future staging (compare the notion of "hypothetical performance text" in Bassnett 1998: 106). Unlike a director's mise-en-scène, the translator's is hypothetical in nature and normally exercised on a textual level; it is also more subtle and less prescriptive, though it has the potential to be informative and instrumental to the performers, offering alternatives and potential handles. Theater translation is a political and artistic undertaking whereby a pre-existing dramatic text is reinterpreted in another language. So instead of creating a single version to be 'all things to all people' (as Visky's Teresa would like to be), the translator may need to consider creating several alternative versions in the target language, in response to the specific cultural references and contexts they wish to illustrate. Irrespective of whether, when and where a translation of a dramatic text is produced, it is essential that opportunities for reflective pausing are factored into the translation journey. Thinking about such 
Komporaly, Jozefina. "Translating Hungarian Drama for the British and the American Stage." Hungarian Cultural Studies. e-Journal of the American Hungarian Educators Association, Volume 14 (2021): http://ahea.pitt.edu DOI: 10.5195/ahea.2021.434

alternatives is a genuinely creative act, and rightly situates the translator as a key collaborator in the performance making process.

\section{Works Cited}

Bassnett, Susan. 1998. "Still Trapped in the Labyrinth: Further Reflections on Translation and theatre”. Eds. Susan Bassnett, André Lefevere. Constructing Cultures: Essays on Literary Translation. Clevedon: Multilingual Matters, 90-108.

Guo, Xiaolu. 2016. “One Language Is Not Enough - I Write in both Chinese and English". The Guardian (London). October 13, 2016. <https://www.theguardian.com/books/2016/oct/13/my-writing-day-xiaolu-guo>

György, Andrea. 2007. 'Szavak böjtje. A kortárs magyar dráma szerepe a színházi nyelv megújításában' ['Fasting Words: The Role of Contemporary Hungarian Drama in the Renewal of Theatrical Language']. Látó, No. 3. 93-102, <http://epa.oszk.hu/00300/00384/00047/632.html> Accessed June 25, 2015.

Komporaly, Jozefina, ed. 2017. András Visky's Barrack Dramaturgy: Memories of the Body. Bristol: Intellect.

Komporaly, Jozefina. 2018. "From Skopje to London via Hungarian and English: András Visky's 'The Unburied'.” The Theatre Times. January 20, 2018.

https://thetheatretimes.com/skopje-london-via-hungarian-english-andras-viskys-unburied/

Komporaly, Jozefina. 2020. "András Visky \& Matéi Visniec: Challenging Boundaries of Cultural Specificity.” Eds. Maria M. Delgado, Bryce Lease and Dan Rebellato. Contemporary European Playwrights. Abingdon-New York: Routledge, 76-94.

Komporaly, Jozefina, ed. 2021. Plays from Romania: Dramaturgies of Subversion. London: Bloomsbury. https://www.bloomsbury.com/uk/plays-from-romania-dramaturgies-of-subversion 9781350214293/

Lehmann, Hans-Thies. 2006. Postdramatic Theatre. Translated and with an introduction by Karen Jürs-Munby. London and New York: Routledge.

Lorraine, Melissa. 2015. E-mail correspondence/interview with the author. June- July. Mother Teresa and Brian Kolodiejchuk. 2007. Come Be My Light. New York: Doubleday. Phelan, Peggy. 1993. Unmarked: The Politics of Performance. London-New York: Routledge. Rokem, Freddie. 2000. Performing History: Theatrical Representations of the Past. Iowa City: University of Iowa Press.

Romanska, Magda, ed. 2014. The Routledge Companion to Dramaturgy. Abingdon-New York: Routledge.

Venuti, Lawrence. 1998. The Scandals of Translation: Towards an Ethics of Difference. Abingdon-New York: Routledge.

Visky, András. 2014. "Barrack Dramaturgy and the Captive Audience.” Ed. Magda Romanska, The Routledge Companion to Dramaturgy. Abingdon-New York: Routledge, 466-471.

Visky, András. 2017. "Temetetlenek. A sötétség szentje”. Látó. No. 10/October. http://www.lato.ro/article.php/Temetetlenek-A-s\%C3\%B6t\%C3\%A9ts\%C3\%A9gszentje/3733/ Accessed 14 June 2021. 
Komporaly, Jozefina. "Translating Hungarian Drama for the British and the American Stage." Hungarian Cultural Studies. e-Journal of the American Hungarian Educators Association, Volume 14 (2021): http://ahea.pitt.edu DOI: 10.5195/ahea.2021.434

Visky, András. 2017. The Unburied: The Saint of Darkness. Directed by Camila França and Trine Garrett, translated by Jozefina Komporaly. Foreign Affairs, London, UK. Premiere: November 20, 2017.

Visky, András. 2018. Stories of the Body. Directed by Melissa Lorraine and Andrej Visky, translated by Jozefina Komporaly. Theatre Y Chicago, USA. Premiere: May 25, 2018. 